\title{
Rancang Bangun Aplikasi Simpan Pinjam Uang Mahasiswa Fakultas Teknik Universitas Asahan Berbasis Web
}

\author{
Helmi Fauzi Siregar ${ }^{1}$, Nilfa Sari ${ }^{2}$ \\ Teknik Informatika, Universitas Asahan \\ Jln. Jend. Ahmad Yani, telp/fax (0623) 347222 \\ fauzi.helmi.hfegmail.com, ${ }^{2}$ sarinilfa06egmail.com
}

\begin{abstract}
Abstrak - Simpan pinjam uang merupakan salah satu kebutuhan manusia. Dimana simpan pinjam uang sebagai sesuatu yang sangat diperlukan untuk mendukung perkembangan kegiatan perekonomian dan meningkatkan taraf kehidupan. Pada perguruan tinggi, terdapat banyak mahasiswa yang mengeluarkan uangnya untuk melakukan pembayaran biaya perkuliahannya. Diantara mahasiswa-mahasiswa tersebut, ada terbilang kurang mampu. Penulis berinisiatif untuk membuat aplikasi simpan pinjam uang yang berguna bagi mahasiswa, apabila mereka sewaktuwaktu membutuhkan dana untuk menyelesaikan administrasi perkuliahan. Mahasiswa juga dapat menyisihkan sebagian uang jajannya untuk disimpan ke dalam aplikasi tersebut. Dengan cara itu, mahasiswa dapat mengurangi sedikit bebannya terkait permasalahan administrasi perkuliahan. Berdasarkan uraian di atas, penulis mengangkat judul penelitian dengan penelitian yang dilakukan langsung terhadap mahasiswa/mahasiswi Fakultas Teknik Universitas Asahan dengan judul "Rancang Bangun Aplikasi Simpan Pinjam Uang Mahasiswa Fakultas Teknik Universitas Asahan Berbasis Web".
\end{abstract}

Kata kunci - aplikasi, simpan pinjam, uang, biaya, mahasiswa, web

\section{PENDAHULUAN}

Kegiatan simpan pinjam uang adalah salah satu kebutuhan manusia. Dimana kegiatan ini telah dilakukan masyarakat sejak masyarakat mengenal uang sebagai alat pembayaran. Hampir semua masyarakat telah menjadikan kegiatan simpan pinjam uang sebagai sesuatu yang sangat diperlukan untuk mendukung perkembangan kegiatan perekonomiannya dan meningkatkan taraf kehidupannya. Bagi perkembangan ekonomi suatu negara, uang merupakan suatu kebutuhan. Bahkan bagi negara maju sekalipun, uang sangat berperan dalam perkembangan ekonomi negaranya. Hal ini disebabkan karena untuk menjalankan pembangunan, uang masih dianggap sektor yang paling vital menurut tinjauan ekonomi.

Pada Fakultas Teknik Universitas Asahan memiliki jumlah mahasiswa/mahasiswi yang lumayan banyak. Diantara mahasiswa/mahasiswi tersebut ada yang terbilang keluarga mampu dan tidak mampu. Pada proses perkuliahan, pasti ada biaya yang harus dikeluarkan. Misalnya uang kuliah, uang praktek, uang ujian, uang omik dan lain sebagainya. Biaya tersebut dapat menghambat mahasiswa/mahasiswi tersebut mengikuti ujian MID ataupun UAS. Dikarenakan biaya yang terlampau banyak, dan waktu yang kurang tepat untuk melakukan pembayaran biaya-biaya tersebut. Dari permasalahan tersebut, penulis mengangkat judul penelitian dengan penelitian yang dilakukan langsung terhadap mahasiswa/mahasiswi Fakultas Teknik dengan judul "Rancang Bangun Aplikasi Simpan Pinjam Uang Mahasiswa Fakultas Teknik Universitas Asahan Berbasis Web".

\section{LANDASAN TEORI}

\section{A. Definisi Rancang Bangun}

Menurut Nurlaila Hasyim (2014), rancang bangun adalah penggambaran, perencanaan, dan pembuatan sketsa atau pengaturan dari beberapa elemen yang terpisah ke dalam suatu kesatuan yang utuh dan berfungsi. Rancang bangun juga merupakan kegiatan menerjemahkan hasil analisa ke dalam bentuk paket perangkat lunak kemudian menciptakan sistem tersebut atau memperbaiki sistem yang sudah ada.

Menurut Taufik Ramadhan (2014), rancang bangun merupakan serangkaian prosedur untuk menerjemahkan hasil analisis dari sebuah sistem kedalam bahasa pemrograman untuk mendeskripsikan dengan detail bagaimana komponen-komponen sistem diimplementasikan. Sedangkan pengertian bangun atau pembangunan sistem adalah kegiatan menciptakan baru maupun mengganti atau memperbaiki sistem yang telah ada baik secara keseluruhan maupun sebagian. Rancang bangun sangat berkaitan dengan perancangan sistem yang merupakan satu kesatuan untuk merancang dan membangun sebuah aplikasi.

Dari definisi tersebut, dapat ditarik kesimpulan bahwa definisi rancang bangun adalah proses perencanaan yang menggambarkan urutan kegiatan (sistematika) mengenai suatu program atau aplikasi. Rancang bangun juga berkaitan dengan perancangan sistem dimana rancang bangun sebagai penerjemah hasil analisa yang dibentuk ke dalam suatu software yang berguna untuk menciptakan sistem atau memperbaiki sistem.

\section{B. Definisi Aplikasi}

Menurut Aris (2016), aplikasi dapat didefinisikan dengan suatu sub kelas perangkat lunak komputer yang memanfaatkan kemampuan komputer langsung untuk melakukan suatu tugas yang diinginkan pengguna. Biasanya dibandingkan dengan perangkat lunak sistem yang mengintegrasikan berbagai kemampuan komputer, tapi tidak secara langsung menerapkan kemampuan tersebut untuk mengerjakan suatu tugas yang menguntungkan pengguna.

Menurut Taufik Ramadhan (2014), aplikasi komputer adalah sebuah perangkat lunak (software) program komputer yang ditulis dalam bahasa 
pemrograman dan berfungsi melakukan perintah sesuai dengan keinginan dari pembuat aplikasi. Aplikasi komputer dibuat untuk memudahkan pengguna dalam mengerjakan sesuatu menggunakan komputer.

Dari pernyataan di atas, penulis menyimpulkan bahwa aplikasi adalah program siap pakai yang dibuat untuuk melaksanakan suatu fungsi bagi pengguna atau aplikasi yang lain dan dapat digunakan oleh sasaran yang dituju. Aplikasi juga merupakan software sistem yang memanfaatkan kemampuan komputer langsung dalam menjalankannya.

\section{Definisi Simpan Pinjam}

Menurut Aris (2016), simpan pinjam merupakan sebuah kegiatan menyimpan dan meminjam uang yang modalnya diperoleh dari simpanan pokok dan simpanan wajib para anggota koperasi. Kemudian modal yang telah terkumpul tersebut dipinjamkan ke para anggota koperasi dan terkadang dipinjamkan kepada orang lain yang bukan anggota koperasi yang memerlukan pinjaman uang, baik untuk keperluan konsumtif maupun modal usaha. Adapun pengertian dari sebagian kalangan mendefinisikan, koperasi simpan pinjam adalah koperasi yang khusus bertujuan melayani atau mewajibkan anggotanya untuk menabung, di samping dapat memberikan pinjaman kepada anggotanya.

Menurut Anggi Mawaddah (2011), simpanan adalah dana yang dipercayakan oleh masyarakat kepada Bank berdasarkan perjanjian penyimpanan dana, sedangkan pinjaman adalah pengalihan hak milik harta atas harta. Jadi simpan pinjam adalah simpanan yang dikumpulkan bersama dan dipinjamkan kepada anggota yang memerlukan pinjaman dalam berbagai usaha dimana anggota mengajukan permohonan tertulis kepada pengurus dengan mencantumkan jumlah uang yang diperlukan.

Dari pernyataan di atas, penulis menyimpulkan bahwa simpan pinjam merupakan suatu kegiatan dimana orang menyimpankan uangnya pada suatu koperasi atau instansi lainnya terkait tempat simpan pinjam uang, dan dapat melakukan peminjaman pada instansi terkait tersebut dengan memberikan syarat berupa permohonan tertulis dengan mencantumkan nominal uang yang akan dipinjamnya.

\section{Definisi Web}

Menurut Akhmad Sholikhin (2013), www atau world wide web atau web saja merupakan sebuah sistem yang saling terkait dalam sebuah dokumen yang berformat hypertext yang berisi beragam informasi, baik tulisan, gambar, suara, video, dan informasi multimedia lainnya dan dapat diakses melalui sebuah perangkat yang disebut web browser. Untuk menerjemahkan dokumen dalam bentuk hypertext ke dalam bentuk dokumen yang bisa dipahami, maka web browser melalui web client akan membaca halaman web yang tersimpan di sebuah web server melalui protocol yang biasa disebut HTTP atau Hypertext Transfer Protocol.
Menurut Alex Fahrudin (2011), website adalah keseluruhan halaman-halaman web yang terdapat dalam sebuah domain yang mengandung informasi.

Dari definisi tersebut, dapat ditarik kesimpulan bahwa web adalah halaman yang saling berhubungan umumnya terletak di pelayan yang sama dan berisi kumpulan informasi yang diberikan oleh individu, kelompok, atau organisasi. Sebuah situs web biasanya ditempatkan setidaknya pada sebuah server web.

\section{E. $P H P$}

Menurut Sri Haryanti (2011), PHP (hypertext preprocessor) adalah sebuah bahasa pemrograman yang berbentuk scripting, sistem kerja dari program ini adalah sebagai interpreter bukan compiler. Artinya semua sintaks yang diberikan akan sepenuhnya dijalankan pada server sedangkan yang dikirimkan ke browser hanya hasilnya saja. Ketika seorang pengguna internet membuka suatu situs yang menggunakan fasilitas server side scripting PHP, maka terlebih dahulu server yang bersangkutan akan memproses semua perintah PHP di server lalu mengirimkan hasilnya dalam format HTML ke web server pengguna internet. Sehingga kode asli yang ditulis dengan PHP tidak terlihat di browser pengguna. PHP tergolong sebagai perangkat lunak open source yang diatur dalam aturan general purpose licences (GPL). Pemograman PHP sangat cocok dikembangkan dalam lingkungan web, karena PHP bisa dilekatkan pada script HTML atau sebaliknya. PHP dikhususkan untuk pengembangan web dinamis. Maksudnya, PHP mampu menghasilkan website yang secara terus menerus hasilnya bisa berubah ubah sesuai dengan pola yang diberikan.

Menurut Aris (2016), PHP singkatan dari hypertext preprocessor yaitu bahasa pemrograman web server-side yang bersifat open source. PHP merupakan script yang terintegrasi dengan HTML dan berada pada server (server side HTML embedded scripting). PHP adalah script yang digunakan untuk membuat halaman yang dinamis (up to date).

Dari pernyataan di atas, penulis menyimpulkan bahwa PHP adalah script yang berjalan dalam server side yang ditambahkan dalam HTML“. Script ini akan membuat suatu aplikasi yang dapat diintegrasikan ke dalam HTML sehingga suatu halaman HTML tidak lagi bersifat statis, namun menjadi bersifat dinamis.

\section{F. $\quad M y S Q L$}

Menurut Sri Haryanti (2011), MySQL merupakan turunan dari salah satu konsep utama dalam basis data sejak lama, yaitu SQL (structured query language). SQL adalah sebuah konsep pengoperasian basis data terutama dapat dikerjakan dengan mudah dan otomatis. Kepopuleran MySQL dimungkinkan karena kemudahannya untuk digunakan, cepat secara kinerja query, dan mencukupi untuk kebutuhan database perusahaan-perusahaan skala menengah kecil. MySQL merupakan database yang digunakan oleh situs-situs terkemuka di internet untuk menyimpan datanya. 
Software database MySQL kini dilepas sebagai software manajemen database yang open source, sebelumnya merupakan software database yang shareware. Shareware adalah suatu software yang dapat didistribusikan secara bebas untuk keperluan penggunaan secara pribadi, tetapi jika digunakan secara komersial maka pemakai harus mempunyai lisensi dari pembuatnya. Software open source menjadikan software dapat didistribusikan secara bebas dan dapat dipergunakan untuk keperluan pribadi atau pun komersial, termasuk di dalamnya source code dari software tersebut. MySQL adalah aplikasi atau sistem untuk mengelola database atau manajemen data. Untuk menyimpan data dan informasi ke komputer kita menggunakan data, contoh kita menyimpan data karyawan pada suatu perusahaan dan memasukan pada suatu file. File data inilah yang disebut database, dan MySQL bertugas mengatur dan mengelola

data-data pada database.

Menurut Alex Fahrudin (2011), my structured query language (MySQL) adalah sebuah program pembuat dan pengelola database atau yang sering disebut Database Management System (DBMS). Sifat dari DBMS ini adalah open source. MySQL juga merupakan program pengakses database yang bersifat jaringan, sehingga dapat digunakan untuk aplikasi multi user (banyak pengguna). Kelebihan lain dari MySQL adalah menggunakan bahasa query (permintaan) standar SQL. SQL adalah suatu bahasa permintaan yang terstruktur, SQL telah distandarkan untuk semua program pengakses database.

Dari pernyataan di atas, penulis menyimpulkan bahwa MySQL adalah sebuah sistem manajemen database yang bersifat open source. MySQL merupakan sistem manajemen database yang bersifat relasional. Artinya data-data yang dikelola dalam database akan diletakkan pada beberapa tabel yang terpisah sehingga manipulasi data akan menjadi lebih cepat. MySQL juga merupakan sebuah software atau perangkat lunak sistem manajemen berbasis data SQL atau juga multi user.

\section{G. XAMPP}

Menurut Dwi Priyanti (2013), XAMPP adalah perangkat lunak bebas, yang mendukung banyak sistem operasi, merupakan kompilasi dari beberapa program. Fungsinya adalah sebagai server yang berdiri sendiri (localhost), yang terdiri atas program apache HTTP Server, MySQL database, dan penerjemah bahasa yang ditulis dengan bahasa pemrograman PHP dan Perl. Nama XAMPP merupakan singkatan dari X (empat sistem operasi apapun), Apache, MySQL, PHP dan Perl. Program ini tersedia dalam GNU (General Public License), merupakan web server yang mudah digunakan yang dapat melayani tampilan halaman web yang dinamis.

Menurut Sri Haryanti (2015), XAMPP adalah perangkat lunak bebas, yang mendukung banyak sistem operasi, merupakan kompilasi beberapa program. Berfungsi sebagai server yang berdiri sendiri (localhost), yang terdiri atas program Apache, MySQL database, dan penerjemah bahasa yang ditulis dengan bahasa pemrograman PHP dan Perl.

Dari definisi tersebut, penulis menyimpulkan bahwa XAMPP adalah sebuah software yang berfungsi untuk menjalankan website berbasis PHP dan menggunakan pengolah data MySQL di komputer lokal. XAMPP berperan sebagai server web pada komputer. XAMPP juga dapat disebut sebuah cpanel server virtual, yang dapat membantu melakukan preview sehingga dapat memodifikasi website tanpa harus online atau terakses dengan internet.

\section{H. $U M L$}

UML (Unified Modeling Language) adalah salah satu alat bantu yang sangat handal di dunia pengembangan sistem yang berorientasi objek. Hal ini disebabkan karena UML menyediakan pemodelan visual yang memungkinkan bagi pengembang sistem untuk membuat cetak biru atas visi mereka dalam bentuk yang baku, mudah di mengerti serta di lengkapi dengan mekanisme yang efektif untuk berbagi (sharing) dan mengkomunikasikan rancangan mereka dengan yang lain.

UML merupakan standar yang relatif terbuka yang di kontrol oleh Object Management Group (OMG), sebuah konsorsium terbuka yang terdiri dari banyak perusahaan. Dimana OMG di bentuk untuk membuat standar-standar yang mendukung interoperabilitas, khususnya untuk sistem berorientasi objek (Deni Mahdiana, 2011).

1) Use Case Diagram

Use case adalah deskripsi dari urutan aksi-aksi yang ditampilkan sistem yang menghasilkan suatu hasil yang terukur bagi suatu actor (Hisyam Wahid Luthfi, 2011).

2) Activity Diagram

Activity diagram yaitu memodelkan alur kerja (workflow) sebuah proses bisnis dan urutan aktivitas dalam suatu proses. Diagram ini sangat mirip dengan sebuah flowchart karena kita dapat memodelkan sebuah alur kerja dari satu aktivitas ke aktivitas lainnya atau dari satu aktivitas ke keadaan sesaat (Hisyam Wahid Luthfi, 2011).

3) Class Diagram

Class diagram adalah sebuah spesifikasi yang jika diinstansiasi akan menghasilkan sebuah objek dan merupakan inti dari pengembangan dan desain berorientasi objek. Class menggambarkan keadaan (atribut/properti) suatu sistem, sekaligus menawarkan layanan untuk memanipulasi keadaan tersebut (metoda/fungsi) (Hisyam Wahid Luthfi, 2011).

\section{METODE PENELITIAN}

Metodologi penelitian adalah sekumpulan peraturan, kegiatan, dan prosedur yang digunakan oleh pelaku suatu disiplin ilmu. Metodologi juga merupakan analisis teoritis mengenai suatu cara atau metode. Adapun teknik pengumpulan data yang dilakukan oleh penulis untuk mendapatkan dan mengumpulkan data adalah sebagai berikut: 


\section{A. Studi Lapangan (Field Research)}

Studi lapangan yang dilakukan dengan cara observasi lapangan langsung ke Fakultas Teknik Universitas Asahan. Dengan menggunakan metode observasi lapangan langsung, penulis melakukan pengamatan secara langsung mengenai kegiatan dan kondisi administrasi mahasiswa Fakultas Teknik, dan mencatat semua informasi yang ada terkait penyusunan penelitian ini.

\section{B. Studi Kepustakaan (Library Research)}

Teknik yang dilakukan yaitu mengumpulkan berbagai sumber referensi baik berupa buku, artikel, jurnal, dan sumber-sumber lainnya sebagai acuan dalam perancangan aplikasi ini serta langkah memecahkan masalah yang berkaitan dengan prosedur pembuatan aplikasi ini.

\section{Penelitian Laboratorium (Laboratory Research)}

Penelitian yang dilakukan untuk menguji program yang telah dirancang sesuai dengan masalah yang ada di Fakultas Teknik tersebut.

\section{HASIL DAN PEMBAHASAN}

\section{A. Analisa Sistem}

Analisa sistem merupakan penguraian dari suatu sistem yang utuh ke dalam bagian-bagian komponennya dengan maksud untuk mengidentifikasi dan mengevaluasi permasalahan. Hal-hal yang dianalisa pada tahap analisa sistem adalah analisa masalah yang sering dialami mahasiswa Fakultas Teknik di perkuliahannya.

\section{B. Perancangan Sistem}

Perancangan didefinisikan sebagai penggambaran, perencanaan dan pembuatan sketsa atau pengaturan dari beberapa elemen yang terpisah ke dalam satu kesatuan yang utuh. Perancangan sistem sangat penting dalam pembuatan suatu sistem, baik dalam sistem apapun. Perancangan sistem yang akan dibuat dimulai setelah melakukan analisis terhadap suatu permasalahan yang terjadi, misalnya pada mahasiswa Fakultas Teknik Universitas Asahan. Adapun perancangan sistem yang akan dibangun disajikan dengan menggunakan UML (Unified Modelling Language) yang terdiri dari use case diagram, activity diagram dan class diagram.
1) Use Case Diagram

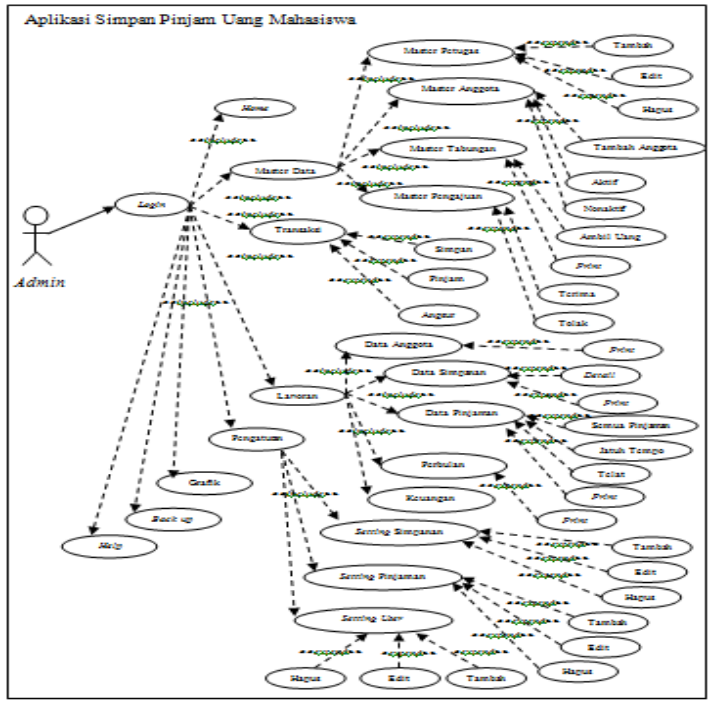

Gambar . 1 Use Case Diagram Admin

2) Activity Diagram

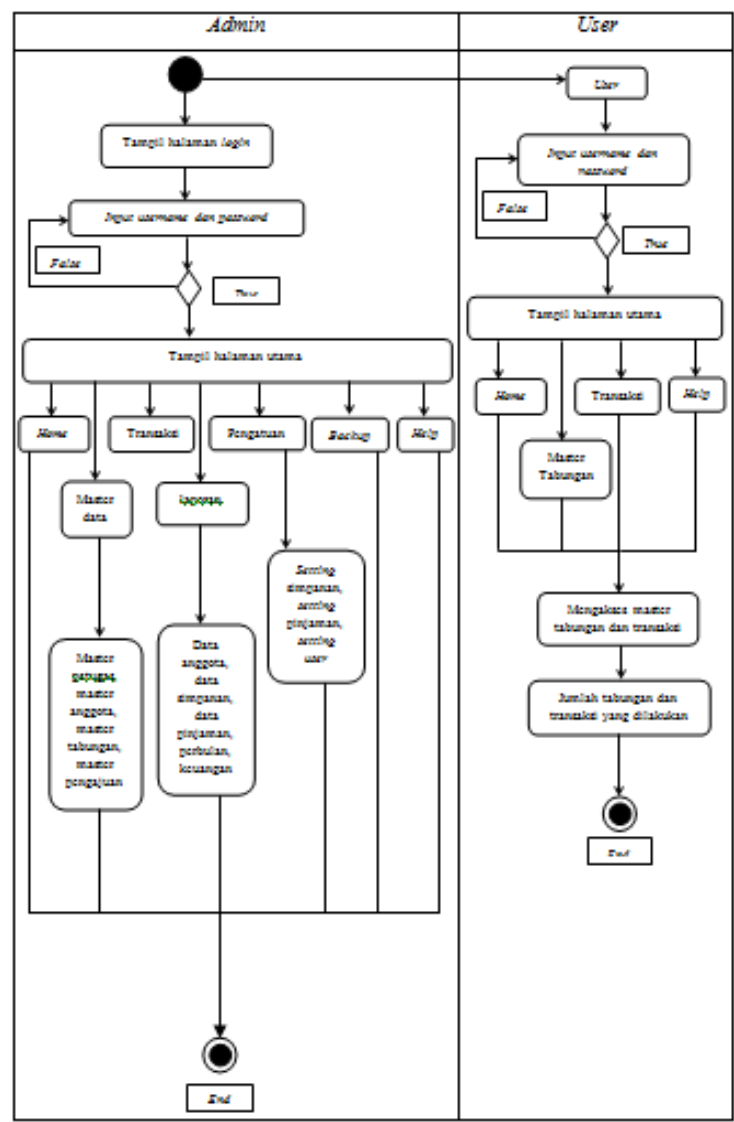


3) Class Diagram

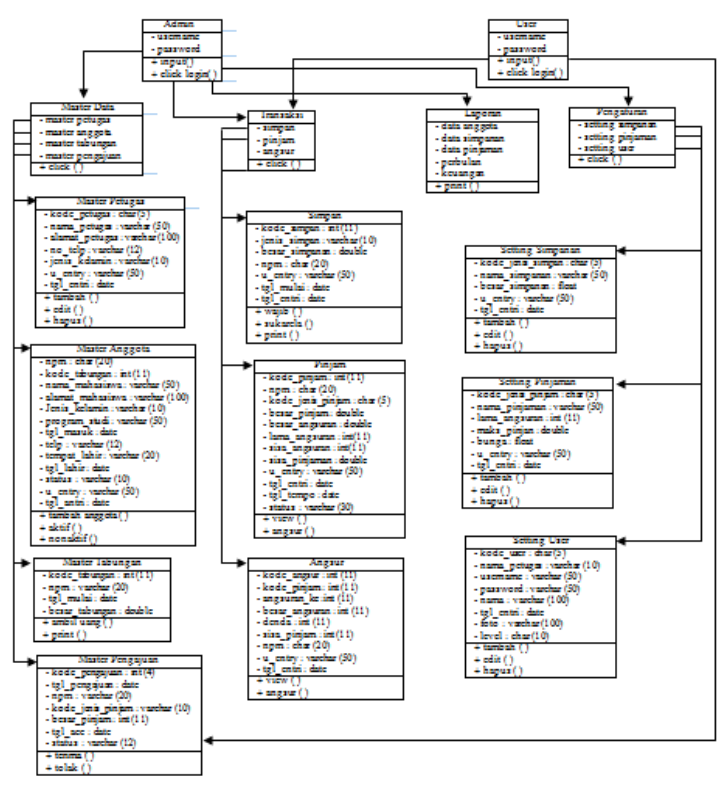

Gambar . 3 Class Diagram

C. Implementasi Sistem

1) Tampilan Menu Login

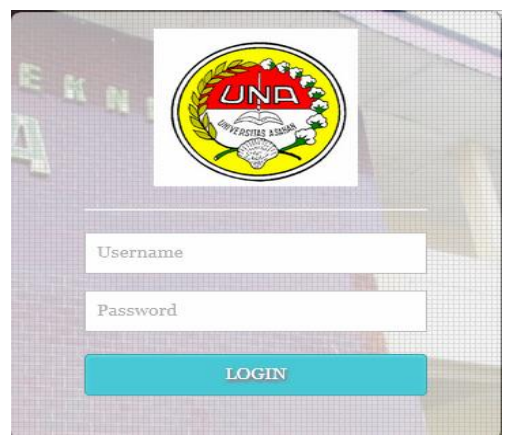

Gambar 4 Class Diagram

2) Tampilan Halaman Utama Admin

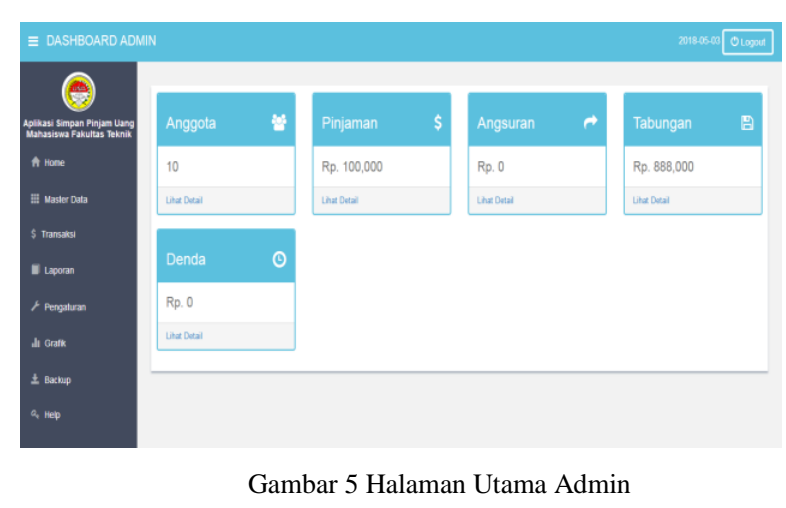

3) Tampilan Master Petugas

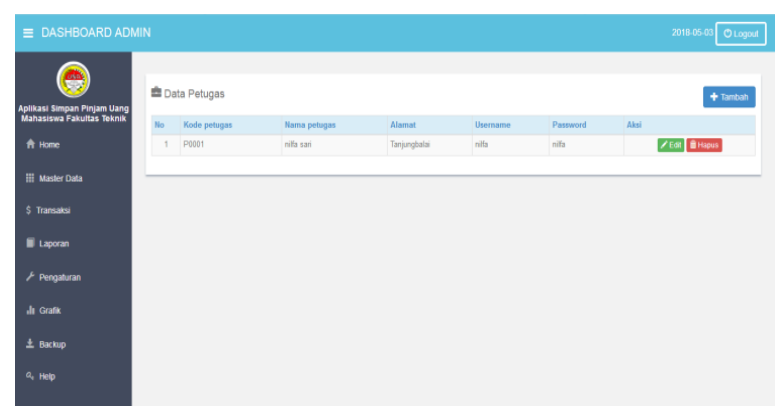

Gambar 6 Master Petugas

4) Tampilan Tambah Data Petugas

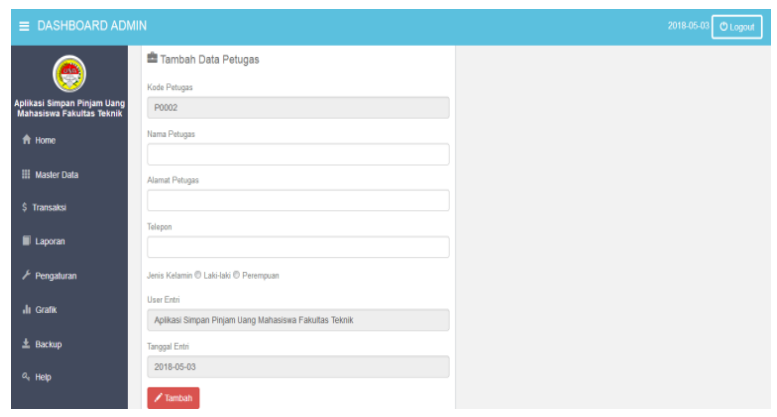

Gambar 7 Tambah Data Petugas

5) Tampilan Master Anggota

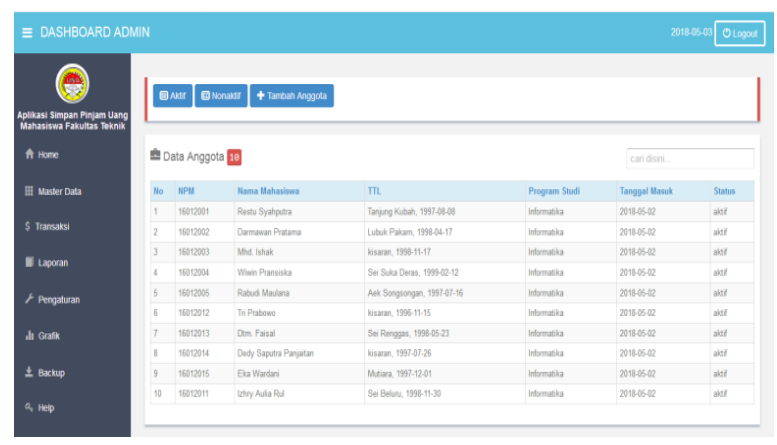

Gambar 8 Master Anggota

6) Tampilan Tambah Data Anggota

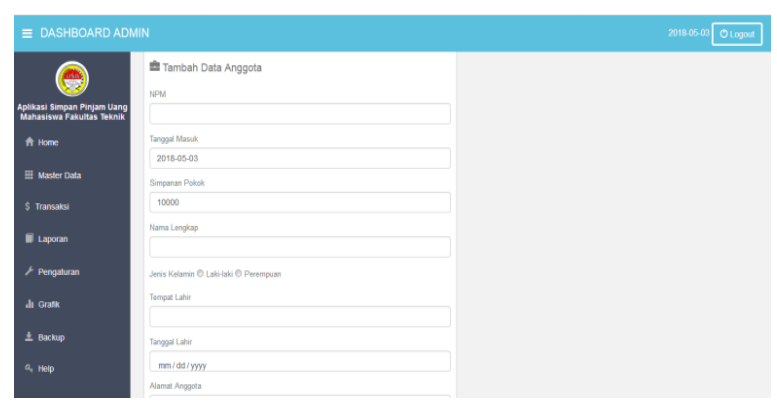

Gambar 9 Tambah Data Anggota 
7) Tampilan Master Tabungan

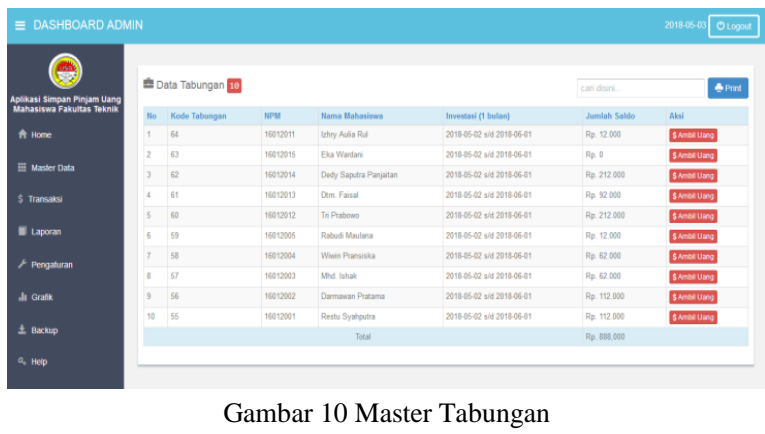

8) Tampilan Master Pengajuan

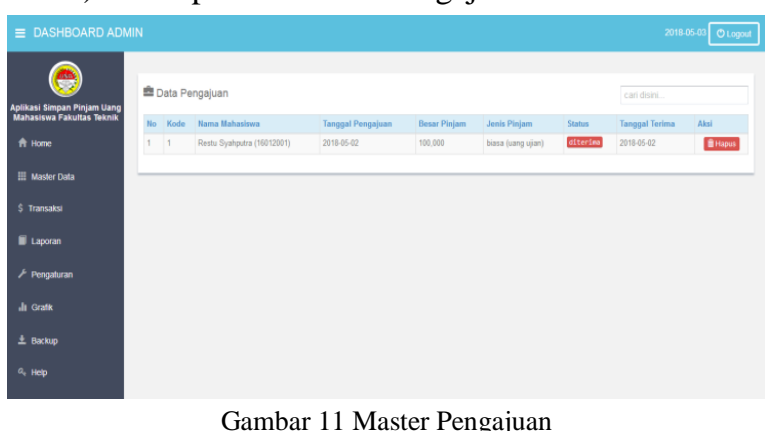

9) Tampilan Menu Transaksi

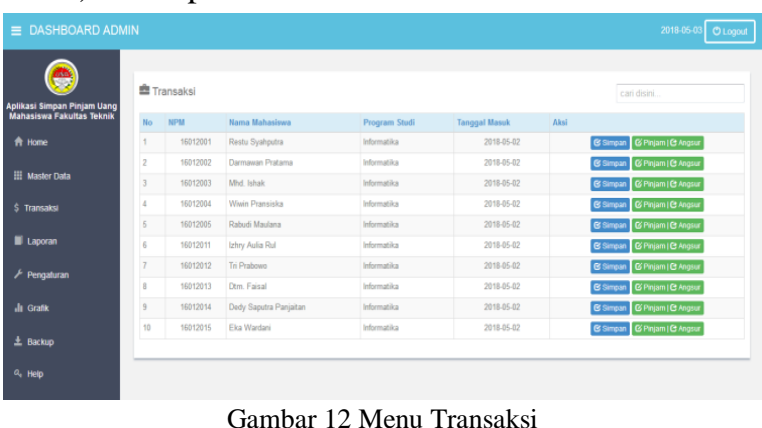

10) Tampilan Laporan Anggota

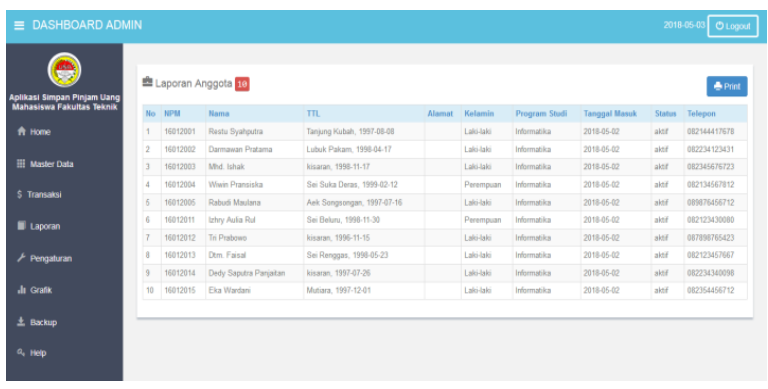

Gambar 13 Laporan Anggota
11) Tampilan Laporan Simpanan

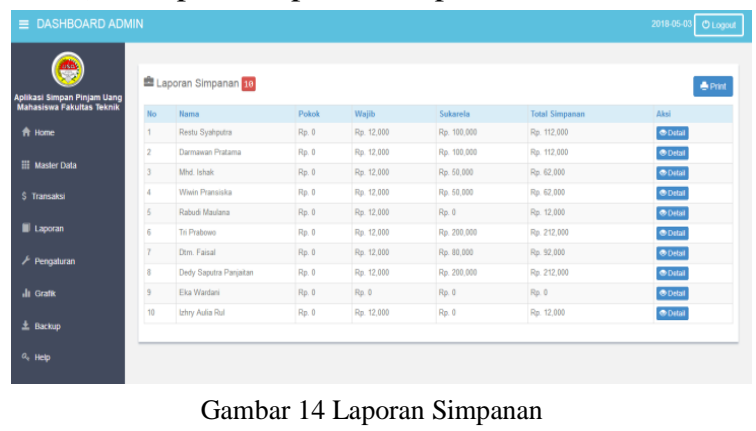

12) Tampilan Laporan Pinjaman

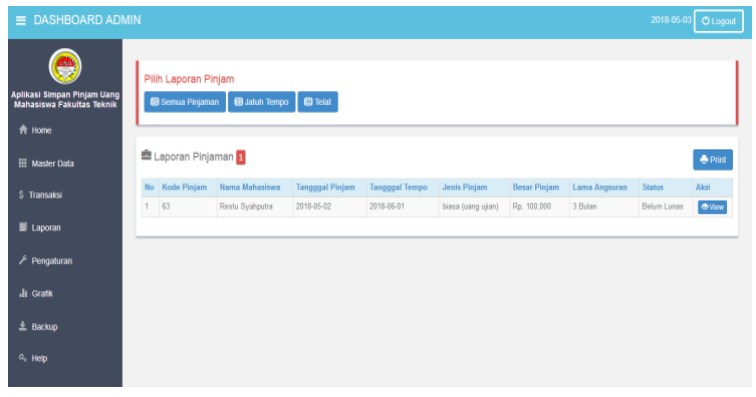

Gambar 15 Laporan Pinjaman

13) Tampilan Laporan Perbulan

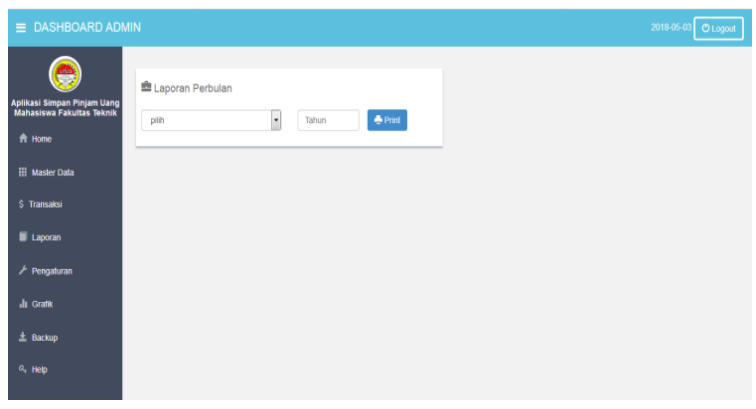

Gambar 16 Laporan Perbulan

14) Tampilan Laporan Keuangan

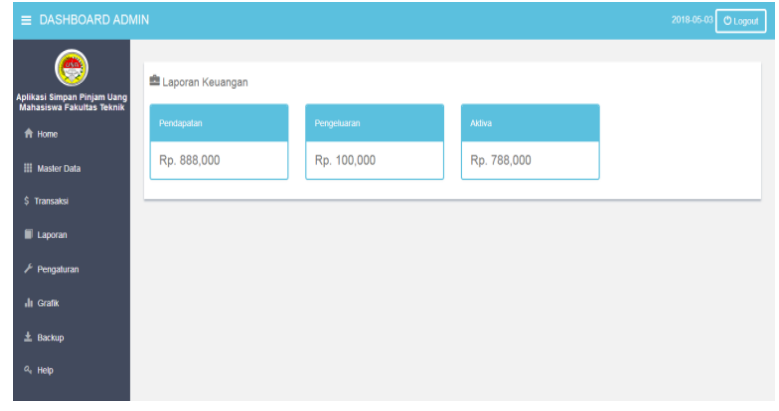

Gambar 17 Laporan Keuangan 
15) Tampilan Halaman Utama User

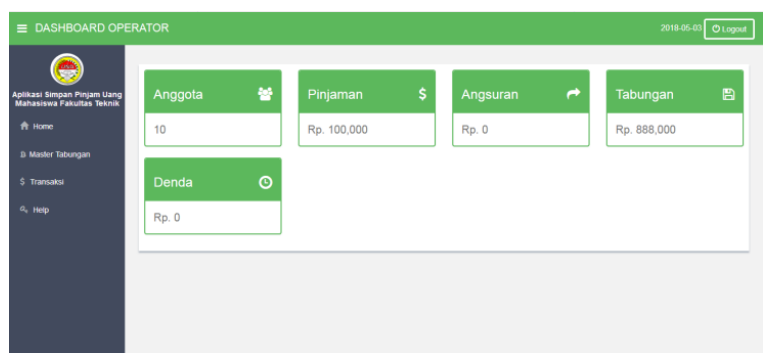

Gambar 18 Halaman Utama User

16) Tampilan Master Tabungan User

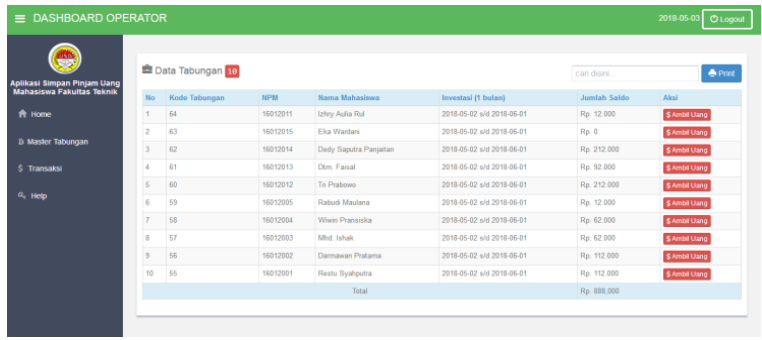

Gambar 19 Master Tabungan User

17) Tampilan Menu Transaksi User

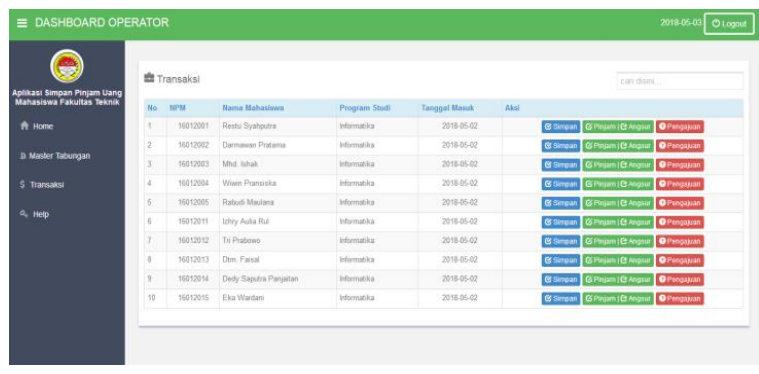

Gambar 20 Menu Transaksi User

18) Tampilan Pengajuan Pinjaman

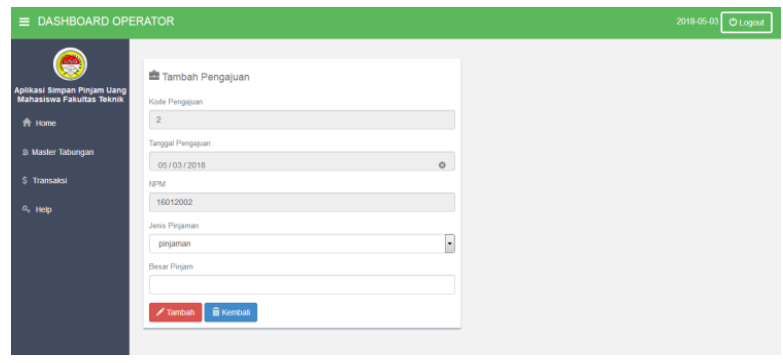

Gambar 21 Pengajuan Pinjaman

\section{KESIMPULAN}

Dari hasil perancangan dan pembuatan aplikasi simpan pinjam uang mahasiswa Fakultas Teknik Universitas Asahan berbasis web, maka dapat diambil kesimpulan sebagai berikut:

1) Dengan adanya aplikasi ini dapat membantu mahasiswa Fakultas Teknik Universitas Asahan dalam menangani permasalahan kuliah yang sebelumnya dialami yaitu masalah dalam bidang administrasi.
2) Aplikasi ini memudahkan admin dan user dalam menangani simpan pinjam uang yang nantinya akan dilakukan oleh mahasiswa Fakultas Teknik Universitas Asahan.

3) Dengan adanya aplikasi ini dapat membantu mempercepat proses administrasi mahasiswa Fakultas Teknik Universitas Asahan dalam menangani administrasi ujian MID ataupun UAS yang sebelumnya pernah terjadi mahasiswa yang tidak mengikuti ujian.

\section{DAFTAR PUSTAKA}

[1] Akhmad Sholikhin. 2013. "Pembangunan Sistem Informasi Inventarisasi Sekolah Pada Dinas Pendidikan Kabupaten Rembang Berbasis Web". IJNS : Vol. 2, No.2. 50-57

[2] Alex Fahrudin. 2011.“ Pembangunan Sistem Informasi Layanan Haji Berbasis Web Pada Kelompok Bimbingan Ibadah Haji Ar Rohman Mabrur Kudus". Universitas Surakarta : Vol.3, No.1. 35-43

[3] Anggi Mawaddah. 2011. "Rancang Bangun Sistem Informasi Simpan Pinjam Mudharabah pada Koperasi Baitul Maal Wat Tamwil ArRum". Universitas Islam Negeri Syarif Hidayatullah Jakarta : Vol.6. 1-6

[4] Aris. 2016. "Aplikasi Sistem Informasi Simpan Pinjam Pada Koperasi Usaha Bersama Syari'ah At-Tahwil Kota Tangerang”. STMIK AMIKOM Yogyakarta. 1-6

[5] Deni Mahdiana, 2011. "Analisa Dan Rancangan Sistem Informasi Pengadaan Barang Dengan Metodologi Berorientasi Obyek : Studi Kasus PT. Liga Indonesia”. Universitas Budi Luhur : Vol. 3, No. 2. 36-43

[6] Dwi Priyanti, 2013. "Sistem Informasi Data Penduduk Pada Desa Bogoharjo Kecamatan Ngadirojo Kabupaten Pacitan". IJNS : Vol. 2, No. 4. 55-61

[7] Hisyam Wahid Luthfi. 2011. "Sistem Informasi Perawatan Dan Inventaris Laboratorium Pada SMK Negeri 1 Rembang Berbasis Web". IJNS : Vol. 3, No.4. 1-9

[8] Nurlaila Hasyim. 2014. "Rancang Bangun Sistem Informasi Koperasi Berbasis Web Pada Koperasi Warga Baru Mts N 17 Jakarta”. Universitas Islam Negeri Syarif hidayatullah Jakarta. 1-11

[9] Sri Haryanti. 2011, "Rancang Bangun Sistem Informasi E-Commerce Untuk Usaha Fashion Studi Kasus Omah Mode Kudus". Universitas Surakarta : Vol. 3, No. 1. 8-14

[10] Sri Haryanti, 2015. "Sistem Informasi Pengelolaan Data Retribusi Perijinan Pasar Gemolong". Universitas Surakarta : Vol. 7, No.2. 20-24

[11] Taufik Ramadhan, 2014. "Rancang Bangun Aplikasi Mobile Untuk Notifikasi Jadwal Kuliah Berbasis Android (Studi Kasus : Stmik Provisi Semarang)". STMIK PROVISI Semarang : Vol. 5, No.2. 47-55 